\title{
as ideias econômicas de heitor ferreira lima: resgatando as obras publicadas nos anos 1950 e $1960^{\star}$
}

\section{the economic ideas of heitor ferreira lima: rescuing books published in the 1950s and 1960s}

\author{
Janaína Fernanda Battahin * \\ Universidade Estadual Paulista “Júlio de Mesquita Filho” (Unesp/FCLAr), Araraquara, SP, Brasil
}

\section{RESUMO}

Este trabalho tem como objetivo resgatar e analisar as ideias econômicas apresentadas por Heitor Ferreira Lima nas obras publicadas nos anos 1950 e 1960. Assim, são apresentadas Evolução industrial de São Paulo (1954), Formação industrial do Brasil: período colonial (1961), Mauá e Roberto Simonsen (1963) e Do imperialismo à libertação colonial (1965), discutindo as especificidades de cada uma delas e a maneira como o autor se apropriou de conceitos como formação, evolução, indústria, técnica etc. Esses trabalhos apresentaram como ideia fundamental a importância do conhecimento da história econômica. O argumento central do autor ligou a ideia de progresso e a superação do atraso do Brasil ao estabelecimento de uma indústria nacional.

Palavras-chave: Heitor Ferreira Lima. História do pensamento econômico. Industrialização. História econômica. Progresso industrial.

\begin{abstract}
This article aims to rescue and analyze the economic ideas presented in Heitor Ferreira Lima's books in the 1950s and 1960s. Thus, the article will present the books Industrial Evolution of São Paulo (1954), Industrial formation of Brazil: Colonial period (1961), Mauá and Roberto Simonsen (1963) and From imperialism to colonial liberation (1965), discussing the specificities of each one of them and the way in which the author appropriated concepts such as training, evolution, industry, technique etc. These works are fundamental to the understanding of the economic history. The author's fundamental argument linked the idea of progress and overcoming the backwardness in Brazil to the establishment of a national industry.
\end{abstract}

Keywords: Heitor Ferreira Lima. History of economic thinking. Industrialization. Economic history. Industrial progress.

* Submissão: 20/02/2020; aprovação: 05/10/2020.

$\star \star$ Doutoranda em Economia no Programa de Pós-Graduação em Economia da Universidade Estadual Paulista “Júlio de Mesquita Filho" (UNESP/FCLAr). Graduada em Economia com Ênfase em Controladoria na Universidade Federal de Alfenas (UNIFAL/MG) e Mestre em Desenvolvimento Econômico pelo Instituto de Economia da Universidade Estadual de Campinas (IE-UNICAMP). Email: janainabattahin@hotmail.com. ORCID: <http://orcid.org/0000-0002-8828-8728>. 


\section{Introdução}

Heitor Ferreira Lima nasceu em Corumbá, no estado do Mato Grosso do Sul, em 1905. Foi um dos grandes nomes do pensamento de esquerda do Brasil juntamente com figuras como Caio Prado Júnior, Octávio Brandão e Astrojildo Pereira. Considerado um dos pioneiros da historiografia econômica brasileira, teve uma formação marxista particular ao ser o primeiro brasileiro a ingressar na Escola Leninista de Moscou em 1927, onde permaneceu três anos (Pinheiro; Roio, 1990). Nessa época, Ferreira Lima enriqueceu suas leituras e estudou história contemporânea, economia política do capitalismo, além de presenciar de perto as decisões do Partido Comunista Soviético e sua relação com os demais países (Roio, 1990).

Apesar de se firmar como nome importante da primeira geração de militantes do Partido Comunista Brasileiro (PCB) nos anos de 1920 e 1930, a partir dos anos de 1940, devido às frustrações dentro do PCB resultantes da luta interna pelo seu controle, iniciou um abandono gradual da militância, limitando-se, a partir de 1945, a acompanhar pela imprensa os acontecimentos do partido (Lima, 1982). Tomou assim, novos rumos e "passou a se preocupar de fato com a definição da sua vida profissional” (Rocha, 1990, p. 19), começando a escrever e publicar em jornais, revistas e livros.

Debruçou-se, então, sobre os estudos de economia e de história econômica (Antunes, 1990). Suas pesquisas se transformaram em uma vultosa obra "pioneira em muitos sentidos, que tem prestado serviços à historiografia brasileira" (Rocha, 1990, p. 17), comtemplando temas como história do Brasil, história econômica, formação industrial e história do pensamento econômico.

Os meus trabalhos eram sempre especializados, referentes ao nosso movimento econômico em geral, com exposições, exames e, às vezes, críticas do desenvolvimento industrial, comercial, agrícola, nível de vida, medidas governamentais estimuladoras ou cerceadoras, assuntos urbanos, bancários, capitais estrangeiros, comentários de relatórios de ministros e líderes patronais. Procurava fazê-los de forma objetiva, como jornalista, tendo em vista o interesse coletivo. Percorrendo-os agora verifico com surpresa que, não obstante o imediatismo com que eram escritos, encerram 
boa parte da vida material do país daquela época, confirmando o que li recentemente num artigo do Tristão de Athayde, ao dizer que o "cronista é o historiador do presente e o historiador é o cronista do passado". (Lima, 1982, p. 268)

Seu trabalho de destaque foi o exercido na Revista Brasiliense entre 1955 e 1964. A revista tinha um caráter mais político e os artigos de Heitor Ferreira Lima não se limitavam apenas aos dados descritivos, mas penetravam mais nos ângulos analíticos e críticos. Esse periódico, aliás, desempenhou importante papel na abordagem das questões nacionais daquele tempo, tendo, para isso, excelentes colaboradores em todos os setores. Por esse motivo, marcou sua época (Lima, 1982).

Em 1944, ingressou na Federação das Indústrias do Estado de São Paulo como membro do Conselho de Economia Industrial, onde permaneceu até a sua aposentadoria. Foi a partir desse trabalho que se especializou como técnico em economia e participou de eventos importante como o Congresso de Bretton Woods (1944) e a Conferência Nacional das Indústrias (1946). Ainda ligado à Federação das Indústrias do Estado de São Paulo, dirigiu a Revista Industrial de São Paulo de 1946 a 1949. Transformou-se, assim, num admirador de Roberto Simonsen (Roio, 2014).

Em 1942, publicou seu primeiro livro: Castro Alves e sua época. Posteriormente, publicou Evolução industrial do Brasil, em 1954; Formação industrial do Brasil, em 1961; Mauá e Roberto Simonsen, em 1963; e Do imperialismo à libertação colonial, em 1965. Nos anos de 1970 e 1980, publicou História político-econômica e industrial do Brasil (1970), Três industriais Brasileiros (1976), História do pensamento econômico no Brasil (1976) ${ }^{1}$, Caminhos percorridos: memórias de militância (1982) e Perfil político de Silva Jardim (1987).

Dessa forma, podemos perceber que Heitor Ferreira Lima tem uma produção significativa sobre a história econômica e industrial do país. Porém, como salientado por Pericás e Secco (2014), não foi um nome de destaque dentro da história do pensamento econômico; ao contrário, o autor é um nome pouco conhecido e, muitas vezes, apontado como um intérprete "renegado" pela academia brasileira.

1 Lançamento de uma segunda edição em 1978. 
Posto isso, este trabalho tem como objetivo resgatar e analisar as ideias econômicas apresentadas por Heitor Ferreira Lima nas obras publicadas nos anos 1950 e 1960, recorte que, além de contemplar um período de rica produção teórica pautada no estudo da história econômica, abrange suas primeiras obras nessa área de estudo, ou seja, seus primeiros trabalhos de fôlego pautados num "sólido arcabouço teórico", o que, de certa forma, marcou o amadurecimento das suas ideias, que até o momento tinham ficados restritas à análises fragmentadas e parciais em jornais e periódicos.

Outro ponto a salientar, é que a partir de meados do século XX, o Brasil passou a vivenciar uma divisão ideológica chamada "controvérsia sobre o desenvolvimento econômico". Essa discussão se dividia entre os que defendiam o liberalismo econômico ${ }^{2}$, preocupados em garantir ao Brasil status de agrário, e os chamados desenvolvimentistas, voltados à implementação da industrialização através da intervenção estatal. Esse dualismo, inclusive, já havia se apresentado na década anterior por meio das figuras de Eugênio Gudin e Roberto Simonsen, mas foi somente nos anos 1950 que o debate ganhou fôlego por meio de instituições e vários outros intelectuais (Mantega, 1984). Assim, até os primórdios de 1950 as análises e orientações teóricas no Brasil provinham de autores como Raul Prebish, Gunnar Myrdal e Ragnar Nurkse; a partir da segunda metade da década, os primeiros trabalhos nacionais surgiram e deram consistência às vozes dos intelectuais brasileiros.

O nome de Heitor Ferreira Lima surgiu em meio a uma geração de intelectuais que pensaram e propuseram mudanças para o Brasil através de um estudo sistemático da realidade brasileira e da construção de um panorama historiográfico nacional. Ferreira Lima fez parte de uma geração que incomodava as elites intelectuais das classes dominantes, e diferente de nomes como Caio Prado Júnior e Celso Furtado, tinha menor influência no estado e na sociedade. O trabalho de Heitor Ferreira Lima ganhou posto secundário e não foi plenamente incorporado no pensamento nacional, o que conferiu à sua obra um caráter "rene-

2 Segundo Mantega (1987, p. 12), consistia em uma "corrente que repetia os velhos princípios da regulação automática do mercado, com sua alocação ótima de recursos e a sublinhar a excelência da Teoria das Vantagens Comparativas." Cita como alguns dos expoentes dessa "corrente ideológica": Eugênio Gudin, Octávio de Bulhões, Glycon de Paiva,Alexandre Kafka,Tristão da Cunga,Aliomar Baleeiro e Bilac Pinto. 
gado" como já apontado anteriormente. Roio (2014,p. 31-32) salientou que talvez Ferreira Lima tenha se transformado em um "intelectual orgânico da burguesia", sempre entusiasta da industrialização e sem senso crítico quanto às classes dirigentes. Além disso, muitas lacunas são apontadas no pensamento do autor, como sua "a noção genérica" dada à indústria", considerando-a como qualquer "atividade transformativa"; os privilégios exagerados à questão da técnica de produção, deixando de lado "o problema das relações sociais e dos processos de trabalho"; e o esquecimento das classes oprimidas na fase de intelectualidade, pois "mal se nota em seus textos a presença dos grupos sociais explorados e oprimidos ao modo de protagonistas" (Roio, 2014, p. 31-32). Mesmo sua obra tendo se constituído sob "um exemplo de interpretação da realidade brasileira que é característica de sua época, em particular os anos 1950 e 1960", ela não alcançou uma articulação mais elaborada e sistemática" (Roio, 2014, p. 27-28). Traçando um comparativo com nomes clássicos, podemos elucidar que Celso Furtado, por exemplo, desvinculou-se de suas origens de "classe média" e rompeu com esquemas de investigação e com a defesa de seus interesses de classe, utilizando um "marco histórico de dimensão regional” (Rodríguez, 1983, p. 954). Alguns intelectuais aplicam o saber "que vem do exterior, considerado validade universal", e talvez Heitor Ferreira Lima tenha sido alocado nesse leque (Mallorquím, 2014, p. 289).

Caio Prado Júnior, por sua vez, apesar de, assim como Ferreira Lima, ter o marxismo como método analítico, já em 1942 apontou uma evolução em ciclos no Brasil: "fases sucessivas de progresso, seguido pela decadência, resultando num sistema e processo econômico em que a produção e o crescimento se subordinavam a contingências extrínsecas" (Pericás; Wider, 2014, p. 193); assim, o desenvolvimento significaria superar esse passado colonial. Em 1933, em Evolução política do Brasil, produziu um "marco nos estudos marxistas brasileiros", dando ênfase às "massas populares e a importância de sua integração à realidade do país" (Pericás; Wider, 2014, p. 195).

Apesar dessas incursões, apontar o motivo de Heitor Ferreira Lima ser um interprete renegado carece de um debate mais aprofundado e conciso. Este artigo talvez possa contribuir, de certa maneira, para que uma parte de sua obra seja esmiuçada e ganhe maior destaque. Embora possa contribuir nesse sentido, o objetivo aqui não é esse. $\mathrm{O}$ objetivo 
deste trabalho consiste em apresentar as obras Evolução industrial de São Paulo (1954), Formação industrial do Brasil: período colonial (1961), Mauá e Roberto Simonsen (1963) e Do imperialismo à libertação colonial (1965), discutindo as especificidades de cada uma delas e a maneira como o autor se apropriou de conceitos como formação, evolução, indústria, técnica etc. Assim, foi feito um esforço para reunir as ideias de Heitor Ferreira Lima sobre passado e seu possível projeto de futuro nessas obras, num esforço de sistematizar seu pensamento e contribuições para a história econômica do Brasil.

Para isso, além desta breve introdução, o trabalho conta com uma segunda parte discutindo as quatro obras salientas; posteriormente, apresentar-se-á algumas conclusões sobre o debate realizado.

\section{Heitor Ferreira Lima e as obras publicadas entre 1950 e 1960}

\subsection{Evolução industrial de São Paulo}

Heitor Ferreira Lima publicou, em 1954, seu primeiro livro sobre história econômica, chamado Evolução industrial de São Paulo, obra na qual acompanhou o processo de industrialização do estado de São Paulo ${ }^{3}$ através da análise de relatos, recenseamentos estatísticos, relatórios de empresas e instituições financeiras - embora assumisse que havia muitas disparidades, em grande parte dos registros industriais, e uma insuficiência de estatísticas.

Considerada uma homenagem ao aniversário de fundação de São Paulo, essa obra apresentou um "esboço histórico" do desenvolvimento industrial da cidade, mostrando a formação do maior parque manufatureiro nacional, com base no material disponível e uma parte já publicada pelo autor na Revista industrial de São Paulo e O observador econômico e financeiro. Mesmo assumindo alguns "vazios" e defeitos, a realização dessa obra se fez necessária porque ninguém até aquele momento havia escrito sobre a "história das nossas realizações no campo industrial". Um dos objetivos da publicação de Evolução industrial de São Paulo, segundo

3 Desde as manufaturas coloniais até a estrutura formada em 1950. 
Ferreira Lima, foi despertar o estímulo dos demais pesquisadores em uma época em que os "estudos de economia ocupavam um lugar de crescente relevo na nossa formação cultural” (Lima, 1954, p. 10).

Nessa obra, três pontos fundamentais merecem atenção: a utilização do termo "evolução" em seu título, a definição de indústria e a associação da indústria ao progresso.

Referente ao primeiro ponto, quando nos indagamos sobre o motivo que levou Heitor Ferreira Lima a utilizar o termo "evolução" no título desse livro, temos que ter a clareza do seu objetivo. O intuito na obra foi destacar três fases do desenvolvimento industrial no estado de São Paulo: a primeira fase, intitulada "período colonial”, que se estendeu até o final do século XVIII; a segunda fase, marcada pela chegada da corte portuguesa ao Brasil no século XIX; e a terceira fase, destacada pelo impulso industrial nos primeiros 50 anos do século XX.

Como se pode observar, o autor abordou uma sucessão de acontecimentos, relacionados à indústria, marcados pelas "mudanças ao longo do tempo" e, no caso, mudanças cada vez melhores. Isso tem total sentido para Heitor Ferreira Lima, pois ao procurarmos o conceito de evolução ${ }^{4}$ no dicionário histórico, encontramos que ele consiste na "mudança ao longo do tempo" e o progresso no "direcionamento para essas mudanças sempre para melhor” (Silva; Silva, 2009, p. 131). É exatamente esse

4 Para "definirmos evolução, precisamos inevitavelmente definir também outro conceito influente na História: progresso", tornando-se essa associação inevitável. A ideia de que "toda evolução é necessariamente um progresso" está na base do pensamento ocidental que sofreu influência da Revolução Industrial. O contexto da Revolução Industrial no século XIX impulsionou a ideia de progresso como "necessário, inevitável e benéfico" para a sociedade, passando a associá-lo ao liberalismo e ao imperialismo. Com a crise de 1929 e a Segunda Guerra Mundial, essa definição de progresso passou por algumas modificações, renascendo com a teoria desenvolvimentista de crescimento econômico do Terceiro Mundo que se alicerçava diante da ideia de que "a Europa (mas agora também os Estados Unidos) era o modelo a ser seguido, e os países não industrializados deveriam se sentir atrasados diante do estágio alcançado pelo capitalismo norte-americano e europeu" (Silva; Silva, 2009, p. 134). Assim, o conceito de evolução, a partir da "ascensão da economia industrial no Ocidente", no século XIX, passou se se associar diretamente ao progresso. Quando Ferreira Lima utilizou o termo "evolução" no título de sua obra, estava se referindo ao conceito ocidental que o associa ao "progresso". Ele relacionou ambos ao processo de ascensão econômica. Ou seja, alicerçou sua ideia no argumento de que precisávamos crescer, assim como os países industrializados. 
significado que o autor buscou atribuir ao título dessa obra: mudanças cada vez melhores nas indústrias ao longo do tempo.

E a característica de cada mudança se tornou crucial para que Ferreira Lima construísse o significado de indústria em sua obra. Quando o leitor se depara lendo sobre os estabelecimentos industriais no Brasil colonial, pode ser tomado por questionamentos e certa confusão. O que seria indústria para Heitor Ferreira Lima? Estaria o autor cometendo anacronismo? Não seria muito pretencioso escrever sobre indústrias nos séculos XVI ao XIX? Para responder a essas perguntas, este trabalho se debruçou sobre as páginas de Evolução industrial de São Paulo antes de qualquer julgamento precipitado ou iníquo. Ferreira Lima sabia exatamente o que queria dizer, pois uma de suas primeiras justificativas na obra de 1954 se refere à utilização da palavra indústria, eximindo-se de qualquer acusação de anacronismo.

Segundo o autor, no livro de 1954, não utilizou o termo indústria, "na moderna acepção da palavra" significado de indústria, no sentido moderno da palavra, ligava-se ao surgimento da máquina automática e à produção em grande quantidade para a exportação. No entanto, essas máquinas só foram utilizadas no Brasil anos mais tarde, e São Paulo, naquele período, vivia de uma "economia quase que primitiva, bastando-se a si mesma”, resumindo-se à lavoura e às atividades primitivas como a "preação de índios, conquista de territórios e descoberta de minas” (Lima, 1954, p.17-25).

Isso evidencia que Ferreira Lima admitiu que a indústria possuía vários sentidos que dependiam de seu contexto/período histórico. Ao abordar a produção no período colonial do estado de São Paulo, utilizou termos como "indústria de tecidos", "grande indústria açucareira" e "atividades industriais". Esses termos foram empregados para se referirem a todas as atividades que elaboravam a matéria-prima e apresentavam um produto acabado com o uso da força humana, considerada técnica rudimentar.

No início do século XIX, com a chegada da corte portuguesa e algumas das suas decisões, ${ }^{6}$ o terreno industrial ficou impossibilitado de

\footnotetext{
5 Ao utilizar o termo "acepção moderna" de indústria, o autor estava se referindo ao seu sentido, já que a palavra acepção significa "sentido em que se emprega um termo". Isto é, refere-se ao sentido da industrialização em cada contexto.

6 A vinda da família real portuguesa ao Brasil teve como reflexo: abertura dos portos
} 
qualquer avanço e expansão. As "únicas medidas de vulto”, em São Paulo, nessa época, foram dois principais empreendimentos na área siderúrgica e outros que, segundo o autor, embora numerosos, não tiveram tanta importância (Lima, 1954, p. 29-34). Nesse contexto, o autor assumiu o termo indústria da mesma maneira que no período colonial: como a transformação da matéria-prima em produto por meio da força braçal.

Já referente ao século XX, Ferreira Lima destacou os primeiros cinquenta anos que marcaram a "industrialização do Brasil”. Industrialização essa que teve como centro principal o estado de São Paulo, representante do "progresso manufatureiro de todo país" (Lima, 1954, p. 50). Esse "impulso da industrialização paulista" foi mensurado pelo autor através do aumento dos estabelecimentos industriais e da qualidade do que se produzia. Pequenas oficinas e fábricas se transformaram em grandes estabelecimentos manufatureiros, a produção dos bens de consumo passou a ter maior variedade e o ritmo de produção de artigos manufaturados cresceu. Assim, São Paulo deixou de ser "meramente agrícola, produtora de café" para se transformar em um importante "centro industrial" como mercadorias variadas e "alto padrão técnico de produção" (Lima, 1954, p. 115).

Ao apresentar detalhadamente o crescimento do número de industriais/fábricas, ${ }^{7}$ Ferreira Lima teve como objetivo mostrar que passamos a produzir mais e importar menos. Nosso padrão técnico possibilitou que começássemos a produzir artigos de consumo imediato; gêneros alimentícios industrializados; ferramentas e outros instrumentos de trabalho; caldeiras; máquinas como teares; pequenas máquinas operatrizes e mecânicas; produtos da indústria pesada, como ferro gusa, aço, laminados, trilhos; e matérias de transporte como vagões para a montagem dos trens no próprio país. Só não produzíamos, ainda, produtos manufaturados que exigiam "elevado aperfeiçoamento técnico" (Lima, 1954, p. 117).

ao comércio mundial; a revogação do Alvará de 1875, proibindo a instalação de fábricas no país; concessão de privilégios alfandegários à Inglaterra, fazendo com que os artigos manufaturados necessários fossem todos importados (Tratado de Comércio e Navegação de 1810).

7 O autor utilizou ambos os termos como sinônimos, embora reconhecesse que estavam longe dessa denominação "na acepção que hoje se dá ao termo" (Lima, 1954, p. 80). 
Essa discussão apontou que, ao adotar o uso da palavra "indústria", Heitor Ferreira Lima tinha em mente o contexto no qual a inseriria, como mostra o quadro a seguir.

\begin{tabular}{|l|l|l|}
\hline \multicolumn{2}{|c|}{ Quadro 1 - O emprego do termo “indústria” em Evolução industrial de São Paulo } \\
\hline \multicolumn{2}{|c|}{ SIGNIFICADO DE INDÚSTRIA } & \multicolumn{1}{c|}{$\begin{array}{c}\text { PADRÃo TÉCNICO EMPREGADO } \\
\text { NA PRODUÇÃO }\end{array}$} \\
\hline $\begin{array}{l}\text { Séculos XVI } \\
\text { ao XVIII }\end{array}$ & $\begin{array}{l}\text { Matéria-prima elaborada e } \\
\text { apresentada como produto acabado. }\end{array}$ & $\begin{array}{l}\text { Padrão técnico rudimentar } \\
\text { (ferramenta manual e força braçal). }\end{array}$ \\
\hline Século XIX & $\begin{array}{l}\text { Matéria-prima elaborada e } \\
\text { apresentada como produto acabado. }\end{array}$ & $\begin{array}{l}\text { Padrão técnico rudimentar } \\
\text { (ferramenta manual e força braçal). }\end{array}$ \\
\hline Século XX & $\begin{array}{l}\text { Matéria-prima elaborada e } \\
\text { apresentada como produto acabado. }\end{array}$ & $\begin{array}{l}\text { "Alto" padrão técnico de } \\
\text { produção/“progresso das forças } \\
\text { produtivas" (máquinas). }\end{array}$ \\
\hline
\end{tabular}

Fonte: elaborado pelo autor.

Assim, Ferreira Lima fez parte do leque de estudiosos que consideraram a indústria "em si mesma", ou seja, considerou-a unicamente como "progresso das forças produtivas", como "progresso técnico" e como "aumento da produtividade", limitando seus estudos dos aspectos sociais em "como seus frutos são repartidos" (Silva, 1986, p. 13). Essa posição de Heitor Ferreira Lima em relação à indústria vai contra a perspectiva que a defende como um processo social "resultado de um sistema complexo de contradições sociais", lutas econômicas, políticas e ideológicas. Nesse conceito, considera-se o surgimento da indústria como "o desenvolvimento das forças produtivas/relações sociais capitalistas toma as formas adaptadas à reprodução das relações de produção dominantes" (Silva, 1986, p. 12). Segundo Silva (1986), na sociedade industrial, as relações de produção capitalista transformam o processo de trabalho.

Dessa maneira, as condições de trabalho capitalistas dominam o trabalhador, indicando "a revolucionarização das forças produtivas pelas relações capitalistas". Como Ferreira Lima não abordou o desenvolvimento da indústria como um processo social, ele acabou dando margem a interpretações que o acusam de "esconder o verdadeiro conteúdo do processo", o qual parece ter um "desenvolvimento neutro (socialmente neutro) das formas produtivas" (Silva, 1986, p. 13-16).

Posto isso, cabe discutir o terceiro ponto: ao esboçar a evolução in- 
dustrial de São Paulo, Heitor Ferreira Lima pretendeu ressaltar a importância da indústria como sinônimo de progresso nacional. Somente a indústria nos levaria rumo "à libertação econômica, ao aproveitamento total das fontes de matérias-primas, ao aumento do nível de vida do povo, ao fortalecimento geral de nossa estrutura econômica" (Lima, 1954 , p. 50). Essa visão ignora alguns pontos fundamentais levantados por Caio Prado Júnior: a formação de um sistema econômico nacional (indústria) associado ao capital estrangeiro reconstrói um sistema colonial, e, por isso, deve-se reconhecer a necessidade de controle das relações internacionais. O desenvolvimento, que para Ferreira Lima é o progresso, deve objetivar a centralidade do mercado interno reconhecendo a importância do planejamento e da intervenção estatal (Paula, 2006, p. 10). Dessa maneira, ao elucidar a transformação de São Paulo em um importante centro industrial composto por fábricas "adiantadas, modernas e de grande capacidade" e a "rapidez do progresso" (Lima, 1954,p. 115-116), deixou de salientar pontos fulcrais. Mesmo que tenha afirmado que São Paulo venceu "em meio século etapas que outros países realizaram em tempos bem maiores", passando de uma economia agrária e semicolonial para um sistema industrial capitalista, com problemas a serem resolvidos, ignorou esse último ponto (Lima, 1954). Portanto, essa obra deu ainda mais força à posição de Ferreira Lima sobre a indústria e sua ligação ao progresso. Vale lembrar que o autor se inseria em um contexto no qual o Brasil e os demais países latino-americanos, conscientes ou não, passaram a adotar uma estratégia desenvolvimentista a partir de 1930, aproveitando-se principalmente do enfraquecimento dos Estados Unidos para "formular estratégias nacionais de desenvolvimento" que implicava principalmente a "proteção da indústria nacional" (Bresser-Pereira, 2006, p. 6-7). Chamados de desenvolvimentistas, os economistas, técnicos do governo, empresários e políticos fizeram propostas de política econômica colocando o desenvolvimentismo como objetivo da análise e da ação econômica e política. Para Bresser-Pereira (2006), entre as décadas de 1940,1950 e 1960, os desenvolvimentistas e keynesianos constituíram o mainstream na América Latina.

\subsection{Formação industrial do Brasil: período colonial}

Heitor Ferreira Lima se dedicou, em 1961, a um trabalho que con- 
templasse a formação da indústria no Brasil no período da colônia. Resultado de quinze anos de pesquisa sobre a nossa história e sobre os problemas industriais que chegaram até o autor (devido às funções que exerceu a partir de 1945 no Conselho de Economia Industrial), e pelo seu gosto em esclarecer um assunto de importância nacional, Formação industrial do Brasil teve como influência fundamental Roberto Simonsen, "entusiasta da industrialização no Brasil" que acreditava que "o nosso progresso se encontrava intimamente ligado ao desenvolvimento industrial" (Lima, 1961, p. 294).

O autor apresentou um levantamento sobre todas as produções realizadas na colônia que consistiam na produção indígena, produção de açúcar, explorações siderúrgicas, produção de tecidos, construção naval, atividades artesanais, casas de moeda e de fundições e outras produções diversas. Para Ferreira Lima, o período colonial foi um período histórico que terminou no final do século XVIII porque a "obra da metrópole estava acabada e nada mais poderia trazer", esgotando-se suas possibilidades. Ao apresentar um balanço do final do século XVIII, chegou à conclusão de que exportávamos mais do que importávamos. Encontrávamo-nos em "pleno desenvolvimento, com apreciável produção e uma participação no comércio internacional não desprezível” (Lima, 1961, p. 294).

Essa situação deu ao povo "consciência nacional" e "aspiração por independência”, originando reivindicações das forças produtoras, comerciantes, lavradores, industriais e capitalistas. Essas reivindicações foram produto dos benefícios provenientes da indústria, as quais poderiam ser ainda maiores se conquistássemos a liberdade de produção e comércio.

A persistência de uma nação inteiramente subordinada à metrópole impedia qualquer avanço industrial e fazia perdurar uma produção sem o desenvolvimento desejado, técnica retardatária, abastecimento insuficiente do mercado interno. Diante desses fatos, ao desembarcar no Brasil, o príncipe regente promulgou as leis que fizeram do país "praticamente independente". Porém, ao nos "libertarmos da dominação colonial, caímos sob a pressão do imperialismo estrangeiro, fazendo isso com que a nossa indústria nascente não encontrasse o almejado campo propício para o seu desenvolvimento". Fomos submetidos mais uma vez aos interesses externos, predominando "as injunções da política internacional, às quais nós tivemos de submeter” (Lima, 1961, p. 305). 
Assim, o autor utilizou a indústria como um motor da história, ou seja, a principal responsável pela mudança de um "período histórico" para o outro: o período colonial para o Brasil Império. Segundo Ferreira Lima, Formação industrial do Brasil: período colonial seria a publicação de um "volume inicial" de uma coleção que apresentaria materiais posteriores - os quais abordariam os demais períodos -, mas que, de fato, não se concretizou. A conclusão a que chegamos é a de que se tratou de uma obra que buscou a origem da indústria no país. Isso faz todo o sentido quando pensamos que Heitor Ferreira Lima utilizou no título desse livro a palavra "formação".

Essa palavra foi utilizada com o intuito de admitir um sentido de constituição, ou parte essencial, de algo. Para analisar a formação da indústria no Brasil, o autor recorreu às origens das atividades produtivas na colônia: a origem da indústria indígena, a origem da indústria açucareira, a origem das explorações siderúrgicas, a origem da construção naval e as origens das demais atividades produtoras coloniais.

Além disso, o autor buscou, também, a origem de dois temas fundamentais para compreender a indústria no contexto mundial: a origem da técnica e a origem da revolução industrial. Esses dois temas se complementaram, no sentido de que Ferreira Lima relacionou a revolução industrial ocorrida na Inglaterra no século XVIII ao surgimento das máquinas na indústria de tecidos. Assim, a máquina de fiar possibilitou a passagem da sociedade feudal para a sociedade capitalista; em outras palavras, a substituição da ferramenta manual pela máquina (Lima, 1961, p. 44). Ao afirmar isso, Ferreira Lima evidenciou, assim como na obra de 1954, que a técnica marcou a evolução da humanidade e a "passagem de uma época histórica para a outra", determinando o "desabrochar das ciências, das letras, das artes e do comércio" e preparando "a era do mundo moderno, em que a indústria iria atingir seu pleno apogeu" (Lima, 1961, p. 20-24).

[...] tem-se ampliado entre nós as pesquisas sobre o nosso passado econômico, o que constitui sintoma salutar e animador, pois dessa forma enriqueceremos um patrimônio de conhecimentos de imensa valia para compreensão do processo de nosso desenvolvimento. (Lima, 1961, p. 5)

Tendo isso em vista, o autor lançou em Formação industrial do Brasil: 
período colonial os alicerces fundamentais de uma história econômica com características próprias. A história econômica em Ferreira Lima, portanto, partia sempre do estudo das origens e acreditava que o motor da história era a técnica. Para completar essa ideia, outra especificidade do autor que se destacou na obra de 1961 foi a definição peculiar de indústria que já havia tomado forma em Evolução industrial de São Paulo.

O fator peculiar diz respeito ao uso do termo indústria para se referir às atividades produtivas desenvolvidas na colônia. Novamente, o autor utilizou essa palavra sem se referir a seu sentido moderno, mas conforme o contexto que se inseria à discussão. Quando se referiu à produção indígena, utilizou a expressão "indústrias indígenas”, embora tenha reconhecido que o termo fora empregado de forma "um tanto exagerado" (Lima, 1961, p. 73). Já referente à “indústria açucareira”, enfatizou que o sentido atribuído foi o "da elaboração da matéria-prima e apresentação no mercado de um produto já acabado, pronto para o consumo imediato" (Lima, 1961, p. 94).

Elucidou também as atividades como a produção de tecidos, a construção naval, as casas de moeda e fundição, o artesanato e as explorações siderúrgicas. Ao abordar, por exemplo, a "exploração siderúrgica", o autor teve como objetivo mostrar como elas auxiliaram no processo industrial em desenvolvimento, pois propiciavam o surgimento de matérias-primas, como o ferro - utilizado na fabricação de armas e instrumentos de trabalho por meio da força braçal.

Essa obra nos faz compreender melhor o conceito de indústria na obra de Heitor Ferreira Lima. A indústria sempre foi considerada pelo autor como todas e quaisquer transformações de matéria-prima em produto acabado. O que define se o termo está sendo utilizado em sua acepção moderna ou não é o padrão técnico de cada contexto histórico. Na colônia, a transformação de matéria-prima em um produto acabado dependia de um padrão técnico rudimentar que consistia na força braçal. Já nos primeiros 50 anos do século XX, foi marcado por um "surto industrial" justamente porque passou a utilizar de um alto padrão técnico.

\subsection{Mauá e Roberto Simonsen}

Em 1963, foi a vez da publicação de Mauá e Roberto Simonsen: dois 
pioneiros do desenvolvimento. Nessa obra, o autor examinou esses dois personagens importantes como "testemunhas, como reflexos, como reveladores de uma época", que, nesse caso, referia-se ao desenvolvimento da industrialização no século XIX e no século XX. A biografia foi utilizada por Heitor Ferreira Lima como instrumento de pesquisa e de saber histórico, embora o saibamos que ela não

[...] tem como vocação esgotar o absoluto do "eu" de um personagem, como já o pretendeu [...]. Ela tampouco tem que criar tipos. Ela é o melhor meio, em compensação, de mostrar as ligações entre passado e presente, memória e projeto, indivíduo e sociedade, e de experimentar o tempo como prova da vida. Seu método, como seu sucesso, deve-se à insinuação da singularidade nas ciências humanas, que durante muito tempo não souberam o que fazer delas. A biografia, assim, é o lugar por excelência da pintura da condição humana em sua diversidade, se não isolar o homem ou não exaltá-lo às custas de seus semelhantes. (Levillain, 2003, p. 176)

Essa, porém, não foi a primeira vez que Ferreira Lima fez uso das biografias como uma ferramenta para fazer história. Em 1942, publicou sua primeira obra, intitulada Castro Alves e sua época, na qual buscou compreender os aspectos da economia e da sociedade europeia, os acontecimentos franceses que condicionaram o comportamento ideológico nacional e o surto industrial brasileiro do século XIX, através da visão histórica de Castro Alves (Lucas, 1990). Em 1954, foi a vez de Evolução industrial de São Paulo, em que dedicou um capítulo sobre as "Figuras pioneiras da industrialização paulista". Nele, discutiu, ainda, a concentração industrial e centralização do capital nas mãos de um pequeno número de famílias e escreveu breves escorços biográficos das figuras pioneiras da industrialização paulista, como Coronel Rodovalho, Conde Matarazzo, irmãos Jafet, Jorge Street, Roberto Simonsen, Comendador Pereira Ignacio e Morvan Dias Figueiredo; apresentando ao leitor os vultosos empreendimentos que esses nomes possibilitaram em uma São Paulo de acanhados recursos e inúmeros obstáculos ao avanço.

Para Ferreira Lima, as biografias desses personagens expressavam "a própria história da grandeza industrial de São Paulo e do Brasil” em um cenário de "contínuo florescimento econômico" (Lima, 1954,p. 155-163). E embora reconhecesse o problema da concentração e centralização industrial nas mãos desse pequeno grupo, acreditava que essas figuras 
tiveram importância fundamental no salto inicial para que a industrialização nacional se tornasse possível. Representavam, assim, um ponto de movimento na história da indústria no estado de São Paulo: o impulso dessa industrialização após um longo período de evolução.

Já Mauá e Roberto Simonsen foi a primeira obra dedicada inteiramente à discussão de dois personagens que marcaram a história da indústria no Brasil. Segundo Ferreira Lima, ele não pretendeu fazer uma biografia desses precursores industriais, mas "focalizar alguns de seus mais importantes empreendimentos". O trabalho sobre Mauá foi publicado no Jornal do Comércio, em 1952, e o trabalho sobre Simonsen fez parte de um livro chamado Homens de São Paulo, publicado pela editora Martins, em 1955. O primeiro, com o intuito de "abordar assuntos e figuras do passado, relacionadas ou de interesse ainda com o presente"; o segundo, para compor "uma série de estudos biográficos de eminentes figuras que avultam na história do Estado Bandeirante, tão rica de personagens" (Lima, 1963, p. 5-6).

Sobre Mauá, Ferreira Lima abordou desde a sua ascensão gloriosa como banqueiro, financista e industrial à sua ruína e falência. Houve quem o visse como um patriota que lutou pelo desenvolvimento do país e quem o julgou como egoísta e ambicioso na busca por seus interesses. A posição adotada pelo autor foi a de um Mauá patriota que, "com sua obra, com suas realizações, cuja evidência não pode ser negada, personificou uma das aspirações do tempo, a aspiração capitalista” (Lima, 1963, p. 29). Mauá se destacou como um homem rico e poderoso que concretizou grandes empreendimentos, como a obtenção de uma grande soma de capitais estrangeiros, que marcaram a renovação da economia de sua época através do surgimento de comércio, dos meios de transporte e comunicação, das primeiras indústrias etc. Porém, esse apoio do capital alienígena se limitou aos empreendimentos de infraestrutura, como serviços urbanos, transportes e comunicação. Ao criar fábricas que produziam artigos de consumo, dando um passo inicial para a industrialização do país, chocou-se com os interesses externos - que tinham no Brasil um mercado para compra de seus produtos. Percebendo esse desfavorecimento do capital estrangeiro, o mercado externo usou algumas estratégias como a diminuição das tarifas de 1860 (Lima, 1963, p. 30-34). Assim, ao agir de forma antagônica aos interesses do capital estrangeiro e como adversário do sistema agrário e escravocrata, Mauá teve seus dias 
de glória contados. Desse escorço sobre Mauá, conclui-se que a opinião de Lima não foi pautada em elogios a um personagem da classe burguesa, mas na importância desse personagem que abriu, "com sua ação fecunda novo capítulo em nossa evolução econômica” (LIMA, 1963, p. 12), uma nova fase de nossa história.

Já sobre Roberto Simonsen, Ferreira Lima não poupou elogios, considerando-o um "estudioso apaixonado dos problemas nacionais" que agiu de maneira "realista, objetiva e prática". Sua admiração perdurou inclusive na reedição dessa obra, em 1976, que recebeu várias modificações, inclusive do título, que passou a se chamar 3 industrialistas brasileiros: Mauá, Rui Barbosa, Roberto Simonsen, porém, continuou a observar o legado do industrial de forma admiradora.

[...] Roberto Simonsen deu ampla demonstração de sua capacidade profissional como engenheiro, levando a cabo obras de vulto, que requeriam aptidão, largos conhecimentos, qualidades de direção e dedicação ao trabalho. Renovou métodos de trabalho em suas atividades, como a introdução, entre nós, do sistema racional de trabalho e legou valiosa experiência, efetuando construção de larga envergadura, em condições dificeis e variadas. (Lima, 1976, p. 160)

Na obra de 1963, Ferreira Lima examinou a obra de Simonsen para evidenciar sua importância como símbolo de uma fase histórica do século XX marcada pela "decadência do sistema agrário de produção e ascensão do sistema do capitalista, com a importância crescente da industrialização" (Lima, 1963, p. 44).

Segundo o autor, a preocupação fundamental de Simonsen foi como elevar a baixa renda nacional. Para isso, elaborou um programa para a economia do país chamado $A$ planificação da economia e apresentou ao Conselho Nacional de Política Industrial e Comercial em 1944. Nesse documento, enfatizou o planejamento, o papel do Estado na economia e a industrialização como meios para aumentar a renda nacional. Simonsen acreditava que não podíamos continuar limitando nossas atividades à exploração da indústria extrativa e do cultivo de terra "a sabor" dos interesses alienígenas por meio da "vassalagem" dos acordos externos (Lima, 1963).

Para que a industrialização fosse possível, guiado pelos preceitos positivistas, Ferreira Lima defendeu um método científico e organizado 
de trabalho para obtenção da máxima eficiência, isso por meio de cursos de profissionalização, popularização de institutos de pesquisa e a viabilização de financiamentos - através da criação de bancos, por exemplo. Consciente de que nossa mão de obra técnico-profissional sofria deficiências, criou a Escola de Sociologia e Política, a fim de preparar especialistas que soubessem dos nossos problemas sociais, econômicos e políticos, encarregando-se da cadeira de História Econômica do Brasil. Não "aspirava somente à formação das elites para assumir a direção de nossos negócios administrativos, públicos e privados", mas defendia que ela atingisse toda a massa da população e criou, com esse intuito, o Serviço Nacional de Aprendizagem Industrial (SENAI). Simonsen “" [...] estimulava os estudos econômicos, incentivava os debates dos problemas nacionais, reunia equipes, financiava pesquisas, ajudava os interessados nesses assuntos" e, nos anos 1920, fundou o Departamento e Conselho de Economia Industrial da Federação e Centro das Indústrias do Estado de São Paulo, propondo estudar os materiais e documentos dessas instituições e acompanhar a evolução econômica e financeira (Lima, 1963). Em 1931, foi a vez do surgimento da Federação das Indústrias do Estado de São Paulo (FIESP), que tinha diretrizes estabelecidas para um programa industrial no Brasil. A partir dessas diretrizes, preparou-se um plano econômico que pôde ser representado no I Congresso Brasileiro de Economia, em 1943.

Roberto Simonsen considerou que o setor privado não estava preparado para fazer face às novas exigências do capital, tecnologia, know-how, capacidade de organização, liderança etc. Por isso, as novas perspectivas de desenvolvimento econômico e, em especial, industrial, exigiam a formulação e utilização de novos instrumentos de ação, incluindo-se o planejamento e o pensamento técnico-cientifico. (Ianni, 1977, p. 55)

Essa exposição das ideias de Simonsen demonstra que a admiração de Ferreira Lima por essa figura foi além. Além porque percebemos, ao esmiuçar a biografia desse pioneiro industrial, que seus preceitos estão presentes na história econômica construída por Ferreira Lima. Assim como Simonsen, Ferreira Lima encontrou na técnica de produção uma maneira de libertar o país da dependência em relação ao exterior. Somente com o aprimoramento técnico, que segundo Simonsen aconteceria 
através da abertura de escolas profissionalizantes e institutos tecnológicos, alcançaríamos a industrialização, mecanismo que possibilitaria a elevação da renda nacional.

Além da técnica como um fator crucial para movimentar nossa história, Simonsen defendeu uma cooperação estrangeira. Organizou, com esse intuito, uma Comissão de Corporação Econômica buscando tornar eficiente essa cooperação estrangeira, principalmente no que se refere à obtenção de auxílio norte-americano e aos planos de desenvolvimento da América Latina. Segundo Simonsen, os norte-americanos deveriam se conscientizar das nossas necessidades e cooperar econômica e tecnicamente ao que tínhamos direito, já que nos sacrificamos na Segunda Guerra Mundial. Seu posicionamento consistia no seguinte: para o financiamento inicial, seriam "empenhados 50\% das disponibilidades que então possuíamos no estrangeiro e seria negociado com os Estados Unidos os suprimentos de que carecêssemos em aparelhos e equipamentos a serem importados, representando esse montante menos de $0,2 \%$ da renda nacional-americana" (Lima, 1963, p. 84-85). Essa posição de Simonsen em relação ao capital estrangeiro serviu de inspiração para Lima, que defendeu a necessidade para o estabelecimento de indústrias sólidas e fortes, porém, com devida autonomia e movido aos interesses nacionais ao invés dos interesses estrangeiros.

Essa ideia também apareceu quando o autor mencionou a ruína de Mauá e apontou que a principal causa consistiu nos interesses antagônicos aos interesses externos. Enquanto Mauá almejava a criação de fábricas que produzissem para o mercado interno, os interesses externos se pautaram na manutenção do mercado para seus produtos. Mauá pôde contar com o fluxo de capital externo somente até o momento em que o utilizou para a exploração de minas, criação de bancos e exploração de serviços públicos como iluminação, transportes, comunicação e urbanização. Isso porque essas obras demandavam grandes quantidades de produtos estrangeiros que só podiam ser adquiridos via importação. Dessa forma, já naquela época, Mauá mostrou que tinha consciência de que os interesses externos eram completamente estranhos aos interesses nacionais; e mesmo reconhecendo a importância do capital alienígena nos primeiros passos rumo à industrialização, admitiu que gerou absoluta dependência econômica e sacrificou nosso desenvolvimento (LIMA, 1963). 
Assim, a obra Mauá e Roberto Simonsen nos mostrou aspectos importantes da história econômica construída por Ferreira Lima.Além de evidenciar sua peculiaridade ao utilizar biografias para fazer história, auxiliou-nos na compreensão da posição do autor sobre o capital estrangeiro e na compreensão da influência de Simonsen em seus escritos.

\subsection{Do imperialismo à libertação colonial}

Em 1965, foi a vez de Do imperialismo à libertação Colonial. Nessa obra, Ferreira Lima colocou em discussão duas noções fundamentais da História Econômica: a noção de que existem diversos "sistemas econômicos" e a noção de "racionalidades econômicas". Para Ferreira Lima, cada sistema econômico tem uma racionalidade econômica que "não é diretamente aplicável ou mesmo válida em relação a uma outra sociedade no tempo e espaço" (Barros, 2008, p. 15). Apontou, nessa obra de 1965, que não podíamos transplantar para sociedades coloniais/subdesenvolvidas a racionalidade típica do capitalismo norte-americano e europeu.

Assim, Ferreira Lima se insere no leque de historiadores econômicos brasileiros que renovam e atualizam o campo da História Econômica. Consciente de que alguns historiadores e economistas historiadores, ao "levantar e analisar economicamente os fatos relativos a uma sociedade econômica", consideravam que as teorias econômicas são universais cometendo a "coleta anacrônica de fatos econômicos do passado", Ferreira Lima propôs a elaboração de postulados e princípios que abarcassem as especificidades e os problemas desses países. A criação de uma teoria que abarcasse esses aspectos particulares libertaria esses países do imperialismo. ${ }^{9}$

Quanto à definição de libertação colonial, devemos atentar a dois conceitos: o de liberdade e o de colonização. $\mathrm{O}$ conceito de liberdade

8 "Conjunto maior que integra de maneira coerente certos fatos econômicos que de outra maneira estariam dispersos, ressaltando que este sistema possui uma historicidade definida - está definida por um conjunto de relações recíprocas que os fatos econômicos de determinado tipo estabelecem entre si” (Barros, 2008, p. 10).

9 Conceito de imperialismo ligado à dependência econômica da América Latina, ou seja, ao domínio financeiro e comercial (Silva; Silva, 2009, p. 218-220). 
desperta uma face "abstrata e filosófica", vigorando, porém, a ideia de "individualismo, como autonomia individual” que dominou a Revolução Francesa e sua luta contra o despotismo e a servidão. Essa luta ganhou força com um "documento símbolo de liberdade", chamado Declaração dos Direitos do Homem. No entanto, outras definições foram aparecendo nas sociedades fora do Ocidente, na escravidão, no cristianismo, na fisica, entre outros.Assim, a liberdade ora teve uma definição prática (liberdade política e econômica), ora teve uma definição filosófica (liberdade interior). $\mathrm{O}$ autor se apropriou da definição prática de liberdade, já que este tipo de liberdade está ligado à necessidade de nações colonizadas, ao se sentirem "tolhidas pelo monopólio metropolitano" e se julgarem "escravas da metrópole", libertarem-se da condição dependente (Silva; Silva, 2009, p. 264-265). A colonização, por sua vez, define-se como conceito e categoria histórica que significa "expansão humana pelo planeta, que desenvolve a ocupação e o povoamento de novas regiões", podendo ter, também, o sentido de "cuidar", "conquistar" e "mandar". No Brasil, esse conceito está ligado à ideia de "domínio, exploração e submissão dos nativos" e às "relações de dependência e controle político e econômico". Obras como Casa grande E senzala, Raízes do Brasil e Formação do Brasil contemporâneo veem a colonização como a explicação dos "problemas sociais" e das "desigualdades" (Silva; Silva, 2009). Essa visão contempla Heitor Ferreira Lima, que empregou o conceito de colonização com esse mesmo sentido.

Para fortalecer a ideia da criação de uma teoria que abarcasse os aspectos particulares dos países subdesenvolvidos, Ferreira Lima esboçou um panorama econômico mundial dos últimos setenta anos (1890 a 1960) dividido em três partes a Primeira Guerra Mundial, a Grande Depressão e o período que se estendeu da Segunda Guerra Mundial à libertação colonial buscando apresentar a teoria econômica/pensamento econômico que prevaleceu em cada um deles (Lima, 1965).

Referente ao início do século XX, o autor destacou o apogeu do capitalismo e do chamado imperialismo, no qual se destacaram "o agrupamento das enormes organizações industriais e monopólios, e o surgimento da oligarquia financeira", bem como a Primeira Guerra Mundial. Diante desse cenário, o principal problema que preocupava os economistas era a distribuição de renda. Em resposta a essa preocupação, o pensamento econômico foi tomado pela formação de três correntes 
distintas: os liberais, ${ }^{10}$ os reformistas sociais ${ }^{11}$ e os socialistas. ${ }^{12}$ Embora o marxismo e o reformismo tivessem influência sob os trabalhadores e alguns intelectuais, prevaleceu o pensamento liberal.

Concernente ao período da Grande Depressão, Ferreira Lima apresentou a crise de 1929 e sua extensão pelos diversos países. A maior contribuição em resposta à crise nesse período entre guerras foi o pensamento do economista John Maynard Keynes, que apontou o abandono dos conselhos clássicos como "a baixa dos salários e manejamento da taxa de juros" como saída para depressão. Os mecanismos keynesianos de intervenção podem ser resumidos em quatro pontos fundamentais: adoção de uma política monetária que colocasse uma quantidade suficiente de moeda em circulação e mantivesse a taxa de juros baixa; aumento dos investimentos públicos; política protecionista; e redistribuição de renda para as classes que mais gastavam (Lima, 1965).

Já relativo ao período da Segunda Guerra Mundial, o autor evidenciou que todos os interesses econômicos se subordinaram a ela, havendo a perda da liberdade econômica, instaurando-se uma economia de guerra. Após a Segunda Guerra, a realidade dos países mudou e, no campo econômico, observou-se uma redução nas relações comerciais da Europa com o resto do mundo. No campo financeiro, muitos países que eram credores saíram como devedores, a exemplo da Inglaterra e da França, que se tornaram dependentes dos empréstimos norte-ame-

10 "Os liberais de 1900 continuavam a identificar liberdade como concorrência, vendo no panegírico da concorrência uma justificação do laissez-faire [...] não admitiam a intervenção do Estado [...] para as angústias e necessidades dos trabalhadores, propunham a criação das Bolsas de Trabalho, que, conjugadas com a concorrência perfeita, tornariam o preço justo" (Lima, 1965, p. 41-42).

11 " [...] tinham por finalidade melhorar as condições de vida e trabalho das classes operárias, começaram a preconizar o desenvolvimento da ação sindical, o lançamento de impostos fundiários progressivos, a criação de cooperativas, a expansão de explorações públicas etc., como remédio para os males sociais da época” (Lima, 1965 , p. 42).

12 " $[\ldots]$ o marxismo havia adquirido dentro dela uma grande influência, com figuras de destaque como Karl Kaustky e Rosa Luxemburgo, na Alemanha; Paul Lafargue e Jules Guesde, na França; Plekhanov e Lenin na Rússia. Na Inglaterra, o socialismo era representado pelo trabalhismo que tinha como ideológicos os 'Fabianos', agrupamento de intelectuais de grande projeção, como Sidney e Beatriz Webb, Bernand Shaw, H. G.Wells e J. Hobson, que não passavam de reformadores sociais empíricos" (Lima, 1965, p. 42). 
ricanos. Tinha-se um ambiente de decadência que "comprometeu a produção, arruinou comércios e hipotecou finanças por muitos anos" (Lima, 1965, p. 136). Diante disso, os Estados Unidos elaboraram o Plano Marshall, um programa de recuperação dos países europeus (reconstrução dos Aliados) via crédito americano aos países destruídos. A partir desse Plano, foram criadas duas importantes instituições: o Fundo Monetário Internacional (FMI) e o Banco Internacional de Reconstrução e Desenvolvimento, propondo a "manutenção da estabilidade monetária para facilitar o crédito e a estabilização monetária” (Lima, 1965, p. 136).

A guerra deixou antigas potências como Inglaterra, França, Japão e Itália enfraquecidas. Isso possibilitou que os povos coloniais conseguissem formar "exércitos de libertação" devido ao armamento que conquistaram durante a guerra e o interesse das classes sociais pela emancipação. Exemplos dessa libertação colonial após a Segunda Guerra Mundial foram as colônias do Oriente Médio, da África e de parte da Ásia (Lima, 1965, p. 147-148). Esses países, chamados pelo autor de subdesenvolvidos, tornaram-se "senhores de seus destinos" e, a fim de se libertarem economicamente das metrópoles, criaram indústrias nacionais.

Porém, muitos deles ainda sofriam com os obstáculos da "velha ordem". Para transformar "tamanha envergadura", Ferreira Lima afirmou que deveríamos encontrar postulados e princípios para a realidade dos países subdesenvolvidos, já que as teorias econômicas em voga eram insuficientes e contraditórias. Pois foram "elaboradas em outras épocas e em outros meios", erguidas "dentro de uma base em que o papel assinado às nações subdesenvolvidas era precisamente aquele contra o qual se rebelavam" (Lima, 1965, p. 158) e para países com uma história diferente. O caminho mais curto para solucionar os problemas e as necessidades dos países subdesenvolvidos, segundo Ferreira Lima, era o abandono dessas doutrinas inadequadas. Essa experiência já estava sendo levada a efeito em diversas regiões do mundo por meio de órgãos especializados e de estudos de diversos pensadores. O trecho a seguir ilustra esse ponto

[...] a CEPAL (Comissão Econômica para a América Latina) para o nosso continente e idêntico órgão da ONU para a Ásia, e autores como Paul Baran, Raúl Prebish, Gunnar Myrdal, Albert Hirshman, Paul Sweezy, 
Arthur Lewis, além de outros, com várias tendências. Entre os brasileiros podem mencionar-se os nomes de Roberto Simonsen, Caio Prado Júnior, Celso Furtado e João Paulo de Almeida Magalhães como os de maior destaque. (Lima, 1965, p. 158).

Para que se desenvolvessem teorias que abarcassem a realidade desses países atrasados, era necessário, e fundamental, compreender os problemas que impediam nosso avanço. Para isso, Ferreira Lima apontou, nas últimas páginas de Do imperialismo à libertação colonial, um esboço dos principais problemas que países como o Brasil ainda enfrentavam no início da segunda metade do século XX. O "atraso econômico" e o "lento ritmo de desenvolvimento" ainda persistiam devido aos seguintes fatores:

$\left.1^{\circ}\right)$ manutenção, no total ou em parte considerável, da estrutura agrária pré-capitalista, que os caracterizava; $2^{\circ}$ ) pequeno desenvolvimento da indústria pesada (com raras exceções), freando o processo de industrialização; $3^{\circ}$ ) manutenção, pelos monopólios imperialistas, de fortes posições econômicas e financeiras, que impedem o desenvolvimento nacional; $4^{\circ}$ ) substituição do domínio direto pelo indireto, com a transferência do poder a grupos nacionais ligados ou a serviço dos antigos dominantes; $5^{\circ}$ ) continuação da dependência do mercado internacional para seus produtos de exportação, sempre artigos primários, de cotação decrescente; $6^{\circ}$ participação cada vez maior dos capitais estrangeiros nos limitados processos de industrialização, restringindo assim os volumes de reinvestimento; $7^{\circ}$ ) lenta substituição dos produtos de importação, refletindo-se nas maiores importações de artigos manufaturados, de matérias-primas e equipamentos. (Lima, 1965, p. 163-164)

Assim, somente quando os estudiosos e economistas entendessem esses pontos de atraso da nossa economia, conseguiríamos estabelecer teorias de fato eficazes.

Mais uma vez, o autor buscou oferecer ao presente as experiências do passado, na tentativa de subsidiar as tentativas de solução do presente. Nessa obra, conseguiu evidenciar que "a teoria não é mais que a experiência concentrada" que "encontra na história" o principal "auxílio para sua formulação”. Em Do imperialismo à libertação colonial, Ferreira Lima pode esmiuçar a ideia que apresentou na nota preliminar de Formação econômica do Brasil: período colonial, na qual afirmou que 
É necessário, por conseguinte, estimular por todos os meios, os trabalhos que visam o estudo da História Econômica, pela importância que representa. Nesse sentido podem prestar ajuda de enorme relevância. [...] Seria altamente meritório, além disso, se os governos (federal, estaduais e municipais) se dedicassem também a esse objetivo, mandando elaborar através de órgãos técnicos e do pessoal competente que possuem, estudos de História Econômica regional, estadual, municipal ou simplesmente de algum produto que no passado ou no presente tenha certa magnitude. Somente depois disso é que se poderá levar a efeito uma obra de síntese perfeita a respeito de nosso passado econômico e social. (Lima, 1961, p. 5-6)

Dessa forma, a importância da história apareceu como aspecto fundamental na elaboração de teorias para países subdesenvolvidos. Ao apresentar um esboço econômico mundial e o pensamento predominante em cada período, Ferreira Lima pretendeu comprovar que as teorias econômicas foram criadas em resposta às necessidades dos países desenvolvidos em cada uma das fases apresentadas. Essa ideia já havia sido apresentada na obra Esboços dos fundamentos da teoria econômica, publicada em 1957 por Caio Prado Júnior. Na obra, o autor evidenciou a necessidade de os "países subdesenvolvidos superarem o estatuto em essência e fundamentalmente colonial de sua economia, e se reestruturarem em bases propriamente nacionais", enfatizando que isso só seria possível por meio de "uma política econômica inspirada em concepções em que eles hoje se acham", requerendo "uma nova teoria econômica" (Prado Júnior, 1957, p. 212). ${ }^{13}$

Assim, ambos reconhecem a necessidade da criação de uma teoria econômica que contemple a realidade dos países menos desenvolvidos, que guardam especificidades em relação às economias desenvolvidas. Enfatizam a necessidade da investigação do passado como principal meio para auxiliar na formulação dessas novas teorias, e que, portanto, uma reflexão sobre a história se mostraria crucial para compreender os dilemas do presente. Os autores não pretenderam desenvolver uma teoria, mas realizar apontamentos com a finalidade de articular melhor a teoria e a prática. Apesar de não colocar o Estado numa posição de destaque em suas obras, Ferreira Lima reconhecia que somente com o apoio do

13 Uma análise acerca de alguns aspectos da obra Esboço dos fundamentos da teoria econômica pode ser encontrada em (Silva; Battahin, 2020). 
Estado seria possível instrumentalizar a pesquisa da história no Brasil através de órgãos públicos que dessem apoio aos questionamentos levantados.

\section{Conclusões}

\subsection{Análise do passado e projeto de futuro em Heitor Ferreira Lima}

A leitura dessas obras, publicadas em 1950 e 1960, possibilitou compreender as ideias econômicas de Heitor Ferreira Lima nesse período. Esses trabalhos apresentaram como ideia fundamental a importância do conhecimento da história econômica. $\mathrm{O}$ argumento fundamental do autor ligou a ideia de progresso e a superação do atraso no Brasil ao estabelecimento de uma indústria nacional. Para que o estabelecimento dessa indústria repercutisse da maneira desejada, fazia-se necessário a reconstituição do passado para que não repetíssemos os mesmos erros no futuro. Assim, Ferreira Lima não só incentivou essa reconstituição como também contribuiu para sua concretização, pois, segundo o autor, havia uma ausência de material sobre uma síntese do nosso passado econômico e social (Lima, 1961).

A pesquisa sobre a história econômica do país prestaria ajuda para as "entidades das classes patronais, as fundações e mesmo as grandes empresas, por meio de organizações que já possuem ou por outras que sejam criadas com essa finalidade". O autor acreditava que a instrumentalização de uma síntese perfeita do passado econômico e social nacional caberia ao governo por meio da criação de órgãos técnicos e pessoais (Lima, 1961, p. 6). Dessa forma, compreende-se por que não mediu esforços para esboçar em suas obras a evolução industrial de São Paulo, a formação da indústria na colônia, e analisar a economia mundial.

Em Formação industrial do Brasil, quando o autor salientou que essas pesquisas auxiliariam as classes patronais, Ferreira Lima quis evidenciar que essa classe implementaria a indústria nacional no país. Essa ideia Lima apareceu nas obras em que destacou personagens pioneiros da indústria no Brasil, como Visconde de Mauá, Roberto Simonsen, Jorge Street, Conde Matarazo, Coronel Rodovalho, entre outros nomes. Demonstrou 
por esses indivíduos considerável admiração, principalmente ao reconhecer que industriais como Mauá e Simonsen lutaram pela criação de um mercado interno que substituiria as importações e faria com que o Brasil alcançasse a tão sonhada independência industrial. Admirava o descontentamento de Mauá com a manutenção da estrutura agrária do país de base escravocrata e o não emprego da mão de obra escrava em seus empreendimentos. Reverenciava, também, a preocupação de Roberto Simonsen em elevar a baixa renda nacional e a tentativa de elevar o padrão de vida da população, reconhecendo a importância da ajuda do capital estrangeiro, das técnicas e do protecionismo para o progresso do país via industrialização. Talvez o que mais tenha contribuído para a admiração de Ferreira Lima em relação a Roberto Simonsen tenha sido sua oposição à vassalagem dos acordos externos nos tratados de comércio e o intercâmbio que favoreciam somente os países industrializados.

Constituiu-se, assim, como intelectual que enfatizou o papel da burguesia industrial na formação das indústrias do país, reconhecendo em História do pensamento econômico brasileiro, de 1976, na qual continuou os elogios a Roberto Simonsen, que "a corrente de pensamento econômico melhor adaptada às nossas condições particulares" emergiu da criação do Centro das Indústrias do Estado de São Paulo e do aparecimento de Simonsen "preconizando a industrialização, como meio de erguer o baixo padrão de vida da população e superar o retardamento material em que nos encontrávamos" (Lima, 1976, p. 5).

Essa admiração pela burguesia industrial custou caro ao autor. Recebeu críticas por deixar de lado as classes exploradas e oprimidas e também a discussão sobre a natureza das relações sociais de produção. Esse papel de destaque foi ocupado pelas classes dirigentes e patronais consideradas implementadoras/promovedoras do progresso que tem "poder inelutável e triunfador" (Lima, 1982, p. 290). Essas críticas, inclusive, fizeram com que muitos intelectuais questionassem o marxismo de Ferreira Lima e afirmassem que "a contribuição marxista ao estudo da problemática brasileira” se confundia várias vezes com “os anseios de crescimento e independência nacional” (Lima, 1978, p. 4). Porém, essa ênfase dada às classes patronais não teve como intuito deixar de lado as classes oprimidas. O ponto crucial foi que o autor trabalhou em defesa da indústria como um meio de atingirmos o progresso e, devido ao fato 
da burguesia industrial ser responsável pelo processo de implementação da indústria nacional, enfatizou somente o seu papel.

Críticas também foram direcionadas ao uso da noção de indústria pelo autor, que, segundo Marco Del Roio (2014), é uma noção “genérica". Porém, quando analisamos as obras de Heitor Ferreira Lima, temos clareza do que quis dizer. Segundo o autor, o significado de indústria dependia do contexto no qual se inseria o termo. Ou seja, atribuía-se um sentido para a palavra indústria em cada período da história. ${ }^{14}$ Quando o autor insere o termo indústria para se referir à São Paulo colonial, deixa claro que "indústria, na moderna acepção da palavra, não poderia existir” por várias razões (Lima, 1961, p. 17). Assim, ao se referir à indústria, pensou no progresso produtivo e no aprimoramento técnico decorrente da evolução das manifestações industriais no país. Portanto, o parâmetro utilizado por para mensurar se o termo "indústria" dizia respeito ao sentido moderno da palavra foi o nível técnico.Ao enfatizar, em suas obras, o processo de formação das indústrias como responsável pelas transformações dos períodos históricos, Ferreira Lima admitiu o progresso técnico como a força motriz da história.

É nítido que o campo de interesse de Heitor Ferreira Lima foi o campo da produção, objeto "primordial da historiografia marxista". Todavia, a teoria marxista abordou o conceito de modo de produção procurando dar conta "de toda a produção da vida material de uma sociedade, a partir da apropriação do trabalho humano e da utilização dos meios de produção (matérias-primas, instrumentos)" (Barros, 2008, p. 37-38). Se levarmos isso em consideração, concluiremos que o autor se inseriu "fora" da teoria marxista ao destacar em suas obras as técnicas de produção e deixando de lado as relações de produção. Enquanto o materialismo histórico acreditava que a História "era a história dos modos de produção e da luta de classes”, Ferreira Lima acreditava que ela era a história do progresso técnico (Barros, 2008, p. 37-38).

Por isso, acreditou que precisávamos preparar melhor os trabalhadores investindo na melhoria das técnicas de produção, já que elas demostraram ser responsáveis pela passagem de uma época histórica a outra.

14 Entre os séculos XVI e XIX, referia-se à indústria como matéria-prima elaborada (produto acabado) e padrão técnico rudimentar. No século XX, o termo consiste em matéria-prima elaborada (produto acabado) e alto padrão técnico empregado (máquinas). 
Esse enfoque nas técnicas evidenciou a influência de um paradigma importante utilizado pelo autor para "encaminhar sua leitura da sociedade": o positivismo.

[...] o que se convencionou chamar de positivismo é, na realidade, a escola metódica, influenciada pelo pensamento do filósofo alemão Leopold von Ranke, que supervalorizava o documento e defendia a objetividade na História. A escola metódica teve seu auge no final do século XIX, defendida sobretudo pelos historiadores franceses Langlois e Seignobos, que pregavam uma História narrativa, política, com forte caráter nacionalista. (Silva; Silva, 2009, p. 190)

Esse positivismo foi herdado de sua admiração por Simonsen e tomou forma quando o autor defendeu em sua obra as leis e os métodos objetivos para a sociedade. Isso através do preparo técnico e da realização de pesquisas para diagnosticar os obstáculos ao progresso, apresentando a ciência como o melhor meio para compreender a sociedade, ao invés dos apelos a superstições (Maza, 2004). Porém, como já exposto anteriormente, "nenhum paradigma é melhor que o outro"; longe disso, trata-se de que uma "opção teórica" pode coexistir com outros paradigmas distintos.

Dentre todas essas características presentes nas obras de Heitor Ferreira Lima, uma se mostrou fundamental: a reconstituição do passado. Em Evolução industrial de São Paulo, o autor abordou, pela primeira vez, sua ideia sobre a importância da história, recapitulando-a, posteriormente, em Formação industrial do Brasil. A história, segundo ele, vai além do interesse acadêmico e da curiosidade pelo passado. A história econômica nos permite compreender a formação do país. Da mesma maneira, os defeitos e distorções que constituem a nação. Através da análise da história e de nossas experiências, encontrar-se-iam soluções para o presente. Considerada investigação do passado, além de tudo auxilia a formulação das teorias, como pudemos observar em Do imperialismo à libertação colonial, e não devia ser menosprezada, pois atua como ferramenta necessária na resolução de questões que exigem soluções (Lima, 1954).

O autor realizou todas essas pesquisas, pois sabia que a história auxiliava na solução dos diversos problemas nacionais e cabia ao historiador "oferecer aos seus contemporâneos o leque de experiências do 
passado, que são dotadas de condições para subsidiar o desenvolvimento econômico" (Rocha, 1990, p. 21).

Isso também evidencia por que o autor escolheu discutir, nessas primeiras obras, a evolução industrial de São Paulo, a formação industrial do Brasil no período colonial, os personagens pioneiros na industrialização nacional e a economia mundial de setenta anos (1890-1960). Esboçando a evolução dos ramos manufatureiros em São Paulo, em 1954, Heitor Ferreira Lima mostrou a transição de uma economia agrária semicolonial para um sistema industrial capitalista ainda insuficiente, abrindo caminho para a libertação econômica nacional. O objetivo não foi abordar os motivos dessa insuficiência, e sim esboçar o processo e a concentração industrial de São Paulo, assim como a centralização de capital nas mãos de um grupo de famílias poderosas. Ao analisar a formação industrial do Brasil no período colonial, em 1961, lançou um panorama manufatureiro abordando as atividades indígenas, o ciclo do açúcar e todas as atividades coloniais dos três séculos coloniais, com o objetivo de encontrar os motivos que impediram o avanço colonial. As medidas de dominação da coroa portuguesa impediram a libertação colonial e a solução estaria na emancipação da indústria nacional.

Em Mauá e Simonsen, recapitulou a história desses dois personagens cruciais para a industrialização do país e publicou num período decisivo para o destino do Brasil, no qual se lutava contra o atraso e o subdesenvolvimento.Já na obra de 1965, enfatizou o papel do passado como peça fundamental para discutir as medidas a serem tomadas para solucionar os problemas do presente que consistem na dominação imperialista que impede a formação de uma indústria autônoma e de força própria.

Dessa maneira, Ferreira Lima alicerçou seus esboços históricos sob o pressuposto da determinação econômica - condições materiais determinam os aspectos da vida social -, ou seja, a economia é a "infraestrutura da sociedade" e determina a "ação dos homens no campo político, administrativo e social em geral” (Lima, 1961, p. 6). Dessa forma, sempre traçou panoramas sob aspectos econômicos como a formação e a evolução da indústria e a liberação colonial via industrialização. O motor da história, para Heitor Ferreira Lima, consiste no desenvolvimento da indústria e do progresso técnico, considerados sinônimos de progresso (Rocha, 1990). Ele escreveu em pleno século XX, momento no qual o conceito de evolução, considerado também progresso, estava relacionado 
ao avanço da economia industrial. Assim, ao utilizar esses termos para concretizar seus esboços históricos, o autor fez uso do conceito ocidental, que relacionou evolução e progresso à economia.

Como já vimos, essa ideia de que "o tempo é linear" e "toda evolução é necessariamente um progresso" advinda do Iluminismo e da Revolução Industrial, passou a ser questionada após a Segunda Guerra Mundial. Esse questionamento não se direcionou ao conceito de evolução, mas à ideia de progresso que foi revitalizada por Jacques Le Goff

Hoje, a crítica ao progresso está presente em todas as ciências sociais e humanas, apesar de, como já dissemos, muitas vezes não corresponder à prática. Mas da mesma forma que Foley revitalizou a ideia de evolução, o historiador francês Jacques Le Goff tenta revitalizar a de progresso. Para ele, o progresso pelos direitos humanos deveria ser uma ideia defendida por todos em nossos dias, entendendo essa forma de progresso como a melhoria das condições de vida da humanidade em todas as sociedades. Além disso, ele lembra Lévi-Strauss, que acreditava que o progresso existe em uma diversidade de processos diferentes. Para Lévi-Strauss, a história não é um processo linear de acumulação de conquistas, e nela diversas formas de civilização podem coexistir, representando cada uma um processo diferente de progresso. (Silva; Silva, 2009, p. 1340)

Heitor Ferreira Lima fez uso do conceito ocidental de evolução, que se confunde com o conceito de progresso. Talvez, a maioria das críticas feitas ao autor, que geralmente atribuem a ele o papel de economicista, baseia-se nas ideias difundidas por Le Goff na pós-modernidade. Le Goff defendeu, como observamos no excerto anterior, o "progresso pelos direitos humanos" ligado à "melhoria das condições de vida da humanidade em todas as sociedades" e a ideia de que cada civilização tem um processo "diferente de progresso". Porém, mesmo utilizando o conceito ocidental de evolução/ progresso, Ferreira Lima tinha essa consciência defendida por Le Goff voltada ao caráter mais humano do conceito. Ao se inspirar no positivismo de Simonsen, Ferreira Lima não realizou uma "transposição de realidades históricas diferentes" para o Brasil; pelo contrário, teve consciência de que de nada adiantaria "copiarmos os modelos estranhos", cabendo ao Brasil aproveitar "apenas os ensinamentos técnicos" e adotar "os necessários corretivos de ordem política e social, para evitar a transplantação correlata dos males verificados”. Simonsen 
defendeu a repartição equitativa dos "frutos produzidos pela tecnologia" para a sociedade e se preocupou com a elevação da renda nacional brasileira, demonstrando esses aspectos que visavam à melhoria de vida das sociedades (Lima, 1963, p. 89-90).

Contudo, mesmo tendo essa consciência, a visão de progresso de Heitor Ferreira Lima - baseada no positivismo de Simonsen - mostrou-se, ao longo do tempo, incapaz de "libertar o homem". Ao contrário, "as forças produtivas do capitalismo, justificadas e estimuladas pelo saber científico-tecnológico, só fizeram aumentar a dominação predatória do homem sobre a natureza e do homem sobre o homem", servindo apenas aos que a "possuem e manipulam" (Silva; Silva, p. 58). Assim como Simonsen, embora tenha demonstrado interesse num primeiro momento pela classe trabalhadora, Ferreira Lima buscou o progresso através de "mecanismos que não contemplavam a plena expressão dos direitos políticos das camadas populares” (Maza, 2004, p. 234).

Ferreira Lima viveu num Brasil no qual o debate nacional-desenvolvimentista ganhou força após a perda da hegemonia liberal, colocada em cheque depois da crise no cenário internacional nos anos 1930. O Brasil vivia, naquela época, a efervescência de "novas concepções de desenvolvimento, provocando reações diversas, conforme os interesses em jogo. Era um modo diferente de encarar questões antes não resolvidas, com instrumental teórico até aí aceito quase que como um dogma” (Lima, 1978, p. 5).

Ferreira Lima foi um "homem do seu tempo" e escreveu "para esse tempo”, já que, a partir dos anos 1950, a política desenvolvimentista e industrial ganhou força e reinou durante três décadas através de políticas de forte presença estatal, desenvolvimento do mercado interno e intensificação do processo de substituição de importações. Foi apenas nos anos 1980, com a crise da dívida externa, que o modelo desenvolvimentista perdeu forças. Nessa década, Ferreira Lima publicou uma única obra, Caminhos percorridos. Dessa forma, os escritos dele mostraram a certeza do contexto no qual se inseria o autor.

Segundo Quentin Skinner, o historiador das ideias deve pensar nos textos a partir dos contextos em que foram criados para compreender o que se pretendia ao escrevê-los. Mais do que compreender o que foi dito, é necessário entender "o que o autor em questão pode ter tido a intenção de dizer ao dizer o que disse" (Skinner, 2005, p. 79). Um his- 
toriador das ideias precisa explicar o contexto em que algo foi escrito para assimilar o que o autor quis comunicar, por meio do que diz, aos leitores, e assim encontrar, entre as várias possibilidades de interpretações, a que corresponde ao que se pretende dizer ou às possibilidades de interpretação do dizer. Assim, o conhecimento histórico, que permite identificar os problemas nos quais os autores clássicos escreviam, é inseparável do período em que os textos foram escritos.

\section{Referências}

ANTUNES, R. Um caminho percorrido: a coerência de Heitor Ferreira Lima. In: PINHEIRO, P. S.; ROIO, M. Del. Combates na história: a trajetória de Heitor Ferreira Lima. Rio de Janeiro: Paz e Terra; São Paulo: FAPESP, 1990.

BARROS, J. D. História econômica: considerações sobre um campo disciplinar. Revista de Economia Política e História Econômica, n. 11, jan. 2008.

BRESSER-PEREIRA, L. C. O novo desenvolvimentismo e a ortodoxia convencional. São Paulo: São Paulo em Perspectiva, v. 20, n. 3, 2006. Disponível em <http:// produtos.seade.gov.br/produtos/spp/v20n03/v20n03_01.pdf $>$.Acesso em 9 janeiro de 2019.

IANNI, O. Estado e planejamento econômico no Brasil (1930-1970). Rio de Janeiro: Civilização Brasileira, 1971.

LE GOFF, J. História e memória. Tradução de Bernardo Leitão. Campinas: Editora da UNICAMP, 1990.

LEVILLAIN, P. Os protagonistas: da biografia. In: RÉMOND, R. (Org.). Por uma história política. Rio de Janeiro: Editora FGV, 2003. p. 141-184.

LIMA, H. F. Caminhos percorridos: memórias de militância. São Paulo: Brasiliense, 1982.

LIMA, H. F. Castro Alves e sua época. São Paulo: Saraiva, 1971.

LIMA, H. F. Evolução industrial de São Paulo. São Paulo: Livraria Martins Editora S. A., 1954.

LIMA, H. F. Formação industrial do Brasil: período colonial. Rio de Janeiro: Fundo de Cultura, 1961.

LIMA, H. F. História do pensamento econômico no Brasil. São Paulo: Brasiliana, 1978.

LIMA, H. F. História político-econômica e industrial do Brasil. São Paulo: Companhia Editora Nacional, 1970.

LIMA, H. F. Do imperialismo à libertação colonial. Rio de Janeiro: Fundo de Cultura, 1965.

LIMA, H. F. Mauá e Roberto Simonsen. São Paulo: Editora Edaglit, 1963.

LIMA, H. F. Perfil político de Silva Jardim. São Paulo: Editora Nacional; Brasília, DF: INL, 1987.

LIMA, H. F. 3 industrialistas brasileiros: Mauá, Rui Barbosa, Roberto Simonsen. São Paulo: Alfa-Omega, 1976. 
LUCAS, F. Aspectos da obra de Heitor Ferreira Lima. In: PINHEIRO, P. S.; ROIO, M. Del. Combates na história: a trajetória de Heitor Ferreira Lima. Rio de Janeiro: Paz e Terra; São Paulo: FAPESP, 1990.

MALLORQUím, C. Celso Furtado. In: PERICAS, L. B.; SECCO, L. Intérpretes do Brasil: clássicos, rebeldes e renegados. São Paulo: Boitempo, 2014. p. 287-303.

MANTEGA, Guido. A economia política brasileira. 2.ed. São Paulo-Petropólis: Polis/ Vozes, 1984.

MAZA, F. O idealismo prático de Roberto Simonsen: ciência, tecnologia e indústria na construção da Nação. São Paulo: Instituto Roberto Simonsen, 2004.

PAULA, J. A. de. Caio Prado Júnior e o desenvolvimento econômico brasileiro. Pesquisa \& Debate, São Paulo, v. 17, n. 1 (29), p. 1-19, 2006.

PERICÁS, L. B.; SECCO, L. Intérpretes do Brasil: clássicos, rebeldes e renegados. São Paulo: Boitempo, 2014.

PERICÁS, L. B.; WIDER, M. C. Caio Prado Júnior. In: PERICAS, Luiz Bernardo; SECCO, Lincoln. Intérpretes do Brasil: clássicos, rebeldes e renegados. São Paulo: Boitempo, 2014. p. 193 - 214.

PINHEIRO, P. S.; ROIO, M. Del. Combates na história: a trajetória de Heitor Ferreira Lima. Rio de Janeiro: Paz e Terra; São Paulo: FAPESP, 1990.

PRADO JÚNIOR, C. Esboço dos Fundamentos da Teoria Econômica. São Paulo: Brasiliense, 1961.

ROCHA, A. P. Heitor Ferreira Lima: militante e historiador. In: PINHEIRO, P. S.; ROIO, M. Del. Combates na história: a trajetória de Heitor Ferreira Lima. Rio de Janeiro: Paz e Terra; São Paulo: FAPESP, 1990.

RODRÍGUEZ, A. Los científicos sociales latinoamericanos como nuevo grupo de intelectualies. El trimenstre económico, Cidade do México, FCE, p. 939-962, 1983.

ROIO, M. Del. A formação de um quadro dirigente do PCB. In: PINHEIRO, P. S.; ROIO, M. Del. Combates na história: a trajetória de Heitor Ferreira Lima. Rio de Janeiro: Paz e Terra; São Paulo: FAPESP, 1990.

ROIO, M. Del. Heitor Ferreira Lima. In: PERICAS, L. B.; SECCO, L. Intérpretes do Brasil: clássicos, rebeldes e renegados. São Paulo: Boitempo, 2014. p. 27-38.

SILVA, K.V.; SILVA, M. H. Dicionário de conceitos históricos. São Paulo: Contexto, 2009.

SILVA, S. Expansão cafeeira e origens da indústria no Brasil. São Paulo: Editora Alfa-Omega. 1986.

SILVA, R. P.; BATTAHIN, J. F. Celso Furtado, Caio Prado Júnior e a História do Pensamento Econômico na década de 1950. Revista da Sociedade Brasileira de Economia Política, Niterói, n. 56, p. 110-141, mai./ago. 2020.

SKINNER, Q. Visions of Politics, v. 1. Cambridge: Cambridge University Press, 2005. 